\title{
Image transmission over Gilbert-Elliot and ITU fading channels using DVB-T2 channel coding and QPSK-OFDM
}

\author{
Conference Paper · April 2012
}

DOI: 10.1109/SIU.2012.6204548
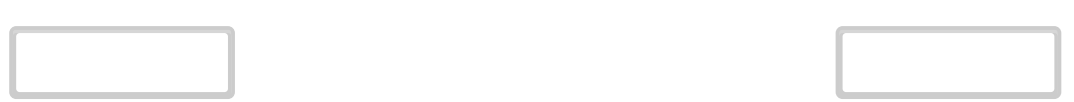


\title{
Gilbert-Elliot ve Sönümlemeli ITU Kanalları Üzerinde DVB-T2 Kanal Kodlanmış QPSK-OFDM ile İmge Gönderimi
}

\author{
Image Transmission over Gilbert-Elliot and ITU Fading Channels \\ using DVB-T2 Channel Coding and QPSK-OFDM
}

\section{Edmond Nurellari}

\author{
Electrical and Electronic Engineering \\ Eastern Mediterranean University \\ edmond.nurellari@cc.emu.edu.tr
}

\author{
Erhan A. Ince \\ Electrical and Electronic Engineering \\ Eastern Mediterranean University \\ erhan.ince@emu.edu.tr
}

\begin{abstract}
ÖZETÇE
$B u$ çalışmada veri ve imgelerin toplanır ve sönümlemeli kanallar üzerinde başarılı bir şekilde gönderimi için ardlş̧k bağlanmış gönderme yönünde hata düzeltim kodları ile dikgen frekans bölüsümlü çoğullama (DFBÇ) birlikte kullanılmıștır. Gönderim benzetimleri Bose Chaudhuri Hocquenghem (BCH) dış kodlayıcısı ve düşük yoğunluklu denetim iç kodlayıcısı kullanarak Gilbert-Elliot kanalı ve Rayleigh sönümlemeli ITU kanalları üzerinde gerçekleştirilmiştir. Benzetim çalışmaları esnasında kullanılan gönderme yönünde hata düzeltim kodları ile ilgili parametreler DVB-T2 standardından alınmıs ve taban bant (TB) çerçeveleri kisaltma ve dolgulama kavramlarından yararlanarak olușturulmuştur. Bit-hata-oranı (BHO) ve görsel olarak sunulan sonuçlar FEC ve DFBÇ' nın kanalın neden verebileceği bozukluklara ne derece dayanıkl olabileceğini göstermektedir. Kötü durumda (state) zincirleme hatalara neden verebilen Gilbert-Elliot kanalını kullanırken, sadece düşük yoğunluklu denetim kodlayıcı (DYDK) ve BCH ile DYDK'nın ardışık bağlandığ durum için elde edilen benzetim sonuçları kıyaslandığında dış BCH kodlayıcının çavlan bölgesinde (waterfall region) $5 d B$ den başlayarak artan bir başarım gösterdiği izlenmiştir. Sönümlemeli ITU-A araç kanalında elde edilen benzetim sonuçları göstermiştir ki hızı $R=1 / 4$ olan DYDK ve BCH-DYDK arasindaki basarım fark ancak $6 d B$ den sonra görülmeye başlanmıştır. BCH-DYDK kullanan QPSK-OFDM sisteminde $3 \times 10^{-4}$ lük bir bit-hataoranı Gilbert-Elliot kanalı için $6 d B$ de yakalanırken ayni BHO ITU-A araç kanalında $6.6 \mathrm{~dB}$ de sağlanabilmiştir.
\end{abstract}

\section{ABSTRACT}

In this work, a concatenated forward error correction (FEC) scheme together with Orthogonal Frequency Division Multiplexing (OFDM) have been used for effective transmission of data/images over additive and fading channels. With a Bose Chaudhuri Hocquenghem (BCH) code as the outer code and a Low Density Parity Check (LDPC) code as the inner code, the transmission has been simulated over both the Gilbert-Elliot and ITU Rayleigh fading channels. The FEC parameters assumed throughout the simulations were obtained from the DVB-T2 standard and the Base Band (BB) frames were created by making use of shortening and zero-padding concepts. The results which have been presented in terms of BER and psycho-visual performances show the resilience of the FEC schemes and OFDM to channel impairments. The BER performances attained over the Gilbert-Elliot Channel (a channel that introduces burst errors when in the bad state) using $L D P C$ only and BCH-LDPC concatenated coding indicated that the outer BCH coding will start to achieve a much lower BER after an SNR of $5 \mathrm{~dB}$. Over the ITU-A Rayleigh fading channel it was observed that the performance increment due to the outer BCH encoder only become apparent after $6 \mathrm{~dB}$ when compared to the rate $1 / 4$ LDPC only coded system BER performance. Over the Gilbert-Elliot channel a BCH-LDPC coded QPSK-OFDM system would provide a BER of $3 \times 10^{-4}$ at $6 \mathrm{~dB}$ while the same BER for the ITU Vehicular-A channel was possible at $6.6 \mathrm{~dB}$.

\section{INTRODUCTION}

Wireless data/image transmission has long become a popular means for information sharing among mobile users. For this reason, it is inevitable for researchers and developers to come up with more effective ways of image transmission regardless of the adverse conditions of the transmission channel. In order to mitigate the effects of the channel on the transmitted data, advanced technologies such as DVB-T2 [1], suggest the use of strong FEC schemes. Among the non-concatenated coding schemes Turbo Codes (TC) and LDPC codes are considered as the two best since their performances near the Shannon limit. In [2], it has been shown that LDPC codes are far better than turbo codes in terms of decoding complexity. They also showed that at low Eb/N0 values, LDPC codes outperform turbo codes in terms of bit error rate performances. At relatively high $\mathrm{Eb} / \mathrm{N} 0$ values however, LDPC codes exhibit an error floor. A general discussion on the error floor of LDPC codes can be found in [3]. It has been stated in [4] that in order to alleviate the error floor problem that occurs under bursty error conditions an outer RS or BCH coder should be serially concatenated with the inner LDPC code. Since in $[5]$ it was shown that the use of an outer $\mathrm{BCH}$ code would provide a lower BER than an outer RS code, in this work a rate $1 / 4$ short FEC frame [1], was simulated.

The results presented herein were obtained via simulations conducted over the bursty Gilbert-Elliot channel and the ITU fading channel models; namely ITU-A and ITU-B. For the simulation of the fading channel the Jakes fading channel model [6], together with ITU Vehicular power delay profile parameters were used assuming a Doppler frequency of 300 Hz. The paper organization is as follows: Section II provides a brief summary about concatenated BCH-LDPC coding as proposed by the DVB-T2 standard and a brief description of how the short FEC frame is formed. In Section III the additive 
Gilbert-Elliot channel model which is known to introduce burst errors while in the bad state was described and the power delay profiles for the vehicular ITU-A and ITU-B fading channels were provided. In section IV the results obtained using the short FEC coding schemes of the DVB-T2 standard are presented and commented on. Lastly in section $\mathrm{V}$ conclusions are drawn.

\section{FORWARD ERROR CORRECTION}

In this section, FEC schemes used in this paper are briefly described.

\subsection{LDPC Coding}

A low-density parity-check code is a linear block code with a low density parity check matrix [7]. LDPC codes are classified into two groups; regular LDPC codes and irregular LDPC codes [8]. Regular LDPC codes have equal column and row weight, and irregular LDPC codes have different column and row weight. Each LDPC code is defined by a matrix $\mathbf{H}$ of size $(m \times n)$, where $\mathrm{n}$ defines the code length and $\mathrm{m}$ defines the number of parity check bits in the code. The number of systematic bits would then be $k=n-m$. The parity check matrix can be represented in the form $\mathbf{H}=\left[\mathrm{I}_{n-k} \mid \mathbf{P}^{\mathrm{T}}\right]$ where $\mathbf{I}_{n-k}$ is Identity matrix and $\mathrm{P}$ is the coefficient matrix. A sample $(3 \times 7)$ parity check matrix is given in (1):

$$
\mathbf{H}=\left[\begin{array}{lll|llll}
1 & 0 & 0 & 1 & 0 & 1 & 1 \\
0 & 1 & 0 & 1 & 1 & 1 & 0 \\
0 & 0 & 1 & 0 & 1 & 1 & 1
\end{array}\right]
$$

Parity-check matrices for the LDPC codes of DVB-T2 standard with code rates $\mathrm{R}(1 / 4,1 / 3,2 / 5,1 / 2,3 / 5,2 / 3,3 / 4,4 / 5$, $5 / 6,8 / 9,9 / 10)$ are possible but in this work we have simulated the performances of $\mathbf{H}$ matrix supporting $1 / 4$. The block length of the code was fixed to 16,200 bits for the short FEC frame mode.

\subsection{BCH Coding}

In simple terms, a $\mathrm{BCH}$ code is a generalized Hamming code that is capable of correcting more than one error in a block. Being algebraically decodable error correcting codes, they have the advantage of low decoding complexity [9] that makes them an attractive choice for the outer code when LDPC is the inner code. The parameters used to describe $\mathrm{BCH}$ codes are as follows: For any integer $m \geq 3$ and $t<2^{m-1}$ there exists a primitive $\mathrm{BCH}$ code with the following parameters:

$$
\begin{gathered}
\mathrm{n}=2^{\mathrm{m}}-1 \\
\mathrm{n}-\mathrm{k} \leq \mathrm{mt} \\
\mathrm{d}_{\text {min }} \geq 2 \mathrm{t}+1
\end{gathered}
$$

This t-error correcting $\mathrm{BCH}$ code can correct $\mathrm{t}$ or fewer errors over a span of $n$ bit positions. $n$ and $k$ are known as the code word and data block respectively. A BCH code is specified by $\mathrm{BCH}(n, k, t)$.

There are a number of BCH codes specified by the DVB-T2 standard which correspond to different code rates. Table 1 shows the available BCH and LDPC parameters for short FEC frame used in the standard. The highlighted cells are the parameters we have used in our simulations. The generator polynomial is obtained by multiplying the first $t$ polynomials provided in [1]. To achieve maximum correction, which in this case is 12 bits per block, all the 12 polynomials shown in
Table 2 must be multiplied over GF(2). The resulting polynomial will be a $168^{\text {th }}$ grade polynomial capable of correcting up to twelve bit errors.

Table 1: FEC Parameters For Short FECFRAME

\begin{tabular}{|c|c|c|c|c|}
\hline $\begin{array}{c}\text { Code } \\
\text { Rate }\end{array}$ & $\mathrm{K}_{\text {bch }}$ & $\mathrm{N}_{\text {bch }}=\mathrm{K}_{\text {ldpc }}$ & $\mathrm{t}$ & $\mathrm{N}_{\text {ldpc }}$ \\
\hline $1 / 4$ & 3072 & 3240 & 12 & 16200 \\
\hline $1 / 3$ & 5232 & 5400 & 12 & 16200 \\
\hline $2 / 5$ & 6312 & 6480 & 12 & 16200 \\
\hline $1 / 2$ & 7032 & 7200 & 12 & 16200 \\
\hline $3 / 5$ & 9552 & 9720 & 12 & 16200 \\
\hline $2 / 3$ & 10632 & 10800 & 12 & 16200 \\
\hline $3 / 4$ & 11712 & 11880 & 12 & 16200 \\
\hline $4 / 5$ & 12432 & 12600 & 12 & 16200 \\
\hline $5 / 6$ & 13152 & 13320 & 12 & 16200 \\
\hline $8 / 9$ & 14235 & 14400 & 12 & 16200 \\
\hline
\end{tabular}

Table2: $\mathrm{BCH}$ polynomials for short FECFRAME

\begin{tabular}{|l|c|}
\hline$g_{1}(x)$ & $1+x^{3}+x^{5}+x^{14}$ \\
\hline$g_{2}(x)$ & $1+x^{6}+x^{8}+x^{11}+x^{14}$ \\
\hline$g_{3}(x)$ & $1+x+x^{2}+x^{6}+x^{9}+x^{10}+x^{14}$ \\
\hline$g_{4}(x)$ & $1+x^{4}+x^{7}+x^{8}+x^{10}+x^{12}+x^{14}$ \\
\hline$g_{5}(x)$ & $1+x^{2}+x^{4}+x^{6}+x^{8}+x^{9}+x^{11}+x^{13}+x^{14}$ \\
\hline$g_{6}(x)$ & $1+x^{3}+x^{7}+x^{8}+x^{9}+x^{13}+x^{14}$ \\
\hline$g_{7}(x)$ & $1+x^{2}+x^{5}+x^{6}+x^{7}+x^{10}+x^{11}+x^{13}+x^{14}$ \\
\hline$g_{8}(x)$ & $1+x^{5}+x^{8}+x^{9}+x^{10}+x^{11}+x^{14}$ \\
\hline$g_{9}(x)$ & $1+x^{2} x^{2}+x^{3}+x^{9}+x^{10}+x^{14}$ \\
\hline$g_{10}(x)$ & $1+x^{3}+x^{6}+x^{9}+x^{11}+x^{12}+x^{14}$ \\
\hline$g_{11}(x)$ & $1+x^{4}+x^{11}+x^{12}+x^{14}$ \\
\hline$g_{12}(x)$ & $1+x+x^{2}+x^{3}+x^{5}+x^{6}+x^{7}+x^{8}+x^{10}+x^{13}+x^{14}$ \\
\hline
\end{tabular}

\subsection{FEC Frame Formation}

The FEC frame is the output of the FEC sub-system when a BB Frame is the input; that is after BCH and LDPC encoding. This frame as specified in [1], and shown in Figure 1, is made up of the BB Frame, BCHFEC, and the LDPCFEC.

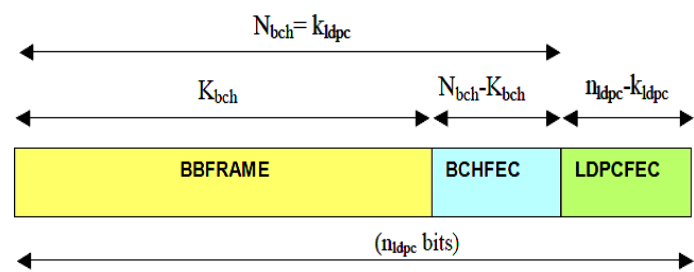

Figure 1: FEC Frame

The BB Frame is of length $\mathbf{K}_{\mathrm{bch}}$ and is the input to the BCH encoder. The $\mathrm{BCH}$ code will require shortening and zero padding if the size of the data to be encoded is not perfectly divisible by $\mathbf{K}_{\mathrm{bch}}$. This padding process is described in [10]. For example, if the size of the transmitted grey scale image is $160 \times 200$ corresponding to a total of 256000 bits; for a code rate of $1 / 4$, the value of $\mathbf{K}_{\mathrm{bch}}$ is 3072 ; this value does not perfectly divide the length of our data thus, if we shorten the 
BCH code by choosing a $\mathbf{K}_{\text {sig }}$ [10] of 2000 , this would mean that the input data will be encoded in 128 separate data blocks each of length $\mathbf{K}_{\mathrm{bch}}$. After BCH encoding, $\mathbf{N}_{\mathrm{bch}}-\mathbf{K}_{\mathrm{bch}}$ parity bits are appended to the $\mathrm{BB}$ Frame and then the resulting output is LDPC encoded to form the FEC frame.

\section{CHANNEL MODELS}

This section provides details about the Gilbert-Elliot channel model and the power delay profiles for the fading ITU Vehicular A and B channels.

\subsection{Gilbert-Elliot Channel}

The Gilbert-Elliot channel model is a hidden Markov model (HMM) which is characterized by two states and the channel transition probabilities. One of these states represents the good (G) state and has lower error probability than the other state which is referred to as the bad (B) state. Structure of the Gilbert-Elliot channel is as shown in Figure 2.

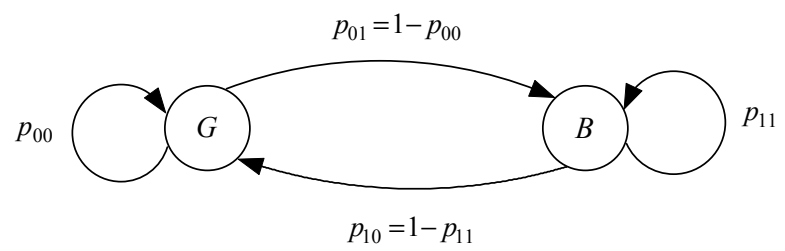

Figure 2:Gilbert-Elliot Channel Model

$p_{i j}$ is the probability of transition from state $i$ to state $j$. In both states the channel behaves like an additive white Gaussian Noise channel but the variance of the noise in the bad state is higher than the variance of the noise in the good state. If a transition to the bad state occurs since $p_{11}$ is high and consequently $p_{I 0}$ is a low probability, for some time the system will remain in this bad state and this will introduce burst errors. In this work the $p_{00}$ and $p_{11}$ probability values assumed were 0.2 and 0.8 respectively and the $\sigma_{B}^{2}=2 * \sigma_{G}^{2}$.

\subsection{Profiles for Vehicular ITU-A and ITU-B channels}

The ITU Vehicular-A and Vehicular-B adopted channel modelsare based on measured data in the field. The tappeddelay-line parameters for these channels have been provided in Table 3. For the simulation of the fading channel the Jakes fading channel model [6] was adopted.

Table 3: Power Delay Profiles for ITU VehIcular Channels

\begin{tabular}{|l|l|l|l|l|l|l|}
\hline \multicolumn{3}{|l|}{ ITU Vehicular -A } & \multicolumn{3}{|l|}{ ITU Vehicular-B } \\
\hline $\begin{array}{l}\text { Tap } \\
\text { Index }\end{array}$ & $\begin{array}{l}\text { Relative } \\
\text { Delay } \\
(\mathrm{ns})\end{array}$ & $\begin{array}{l}\text { Average } \\
\text { Power } \\
(\mathrm{dB})\end{array}$ & $\begin{array}{l}\text { Tap } \\
\text { Index }\end{array}$ & $\begin{array}{l}\text { Relative } \\
\text { Delay } \\
(\mathrm{ns})\end{array}$ & $\begin{array}{l}\text { Average } \\
\text { Power } \\
(\mathrm{dB})\end{array}$ \\
\hline 1 & 0 & 0 & & 1 & 0 & -2.5 \\
\hline 2 & 310 & -1 & & 2 & 300 & 0 \\
\hline 3 & 710 & -9 & & 3 & 8900 & -12.8 \\
\hline 4 & 1090 & -10 & 4 & 12900 & -10.0 \\
\hline 5 & 1730 & -15 & 5 & 17100 & -25.2 \\
\hline 6 & 2510 & -20 & 6 & 20000 & -16.0 \\
\hline
\end{tabular}

\section{SIMULATION RESULTS}

This section provides the simulation results in three parts. First, the BER performance and psycho-visual analysis of rate $1 / 4$ LDPC-only and concatenated BCH-LDPC coded QPSKOFDM over the Gilbert-Elliot channel is presented. Following this the BER performance of LDPC only coded QPSK-OFDM system is investigated over the ITU Vehicular-A and Vehicular-B channels and performances attained in each case are compared. Lastly the BER performance and psycho-visual analysis for LDPC only and BCH-LDPC coded QPSK-OFDM over the ITU Vehicular-A channel is provided. In all simulations the external $\mathrm{BCH}$ encoder adopted is $\mathrm{BCH}$ $(3072,3240,12)$ with an effective code rate of $1 / 5$. Figure 3 shows the BER performance over the Gilbert-Elliot channel for the LDPC only and BCH-LDPC cases.

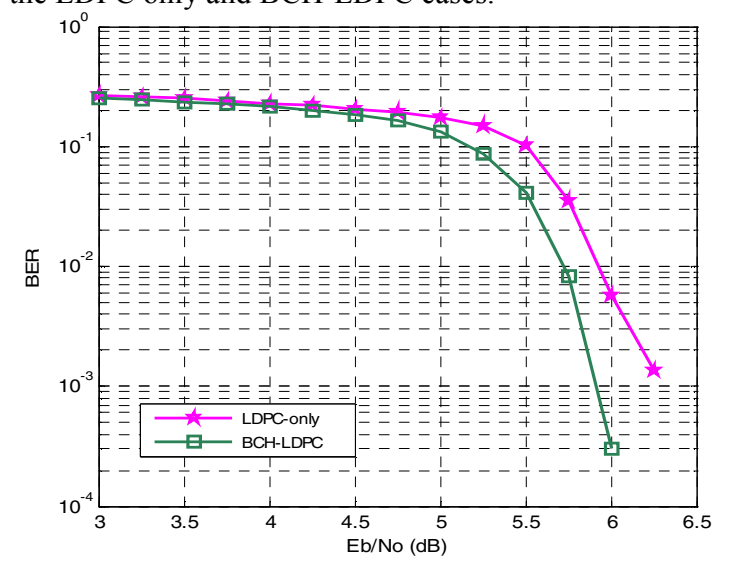

Figure 3: BER performance for LDPC vs BCH-LDPC coded QPSK-OFDM over the Gilbert-Elliot Channel

Note here that, even though the input message is one million bits long since the channel is introducing burst errors the best BER attained even when BCH-LDPC channel coding is used is around $10^{-4}$ at an SNR of $6 \mathrm{~dB}$. The decoded images for the Gilbert-Elliot channel are as shown in Figures 4 and 5.

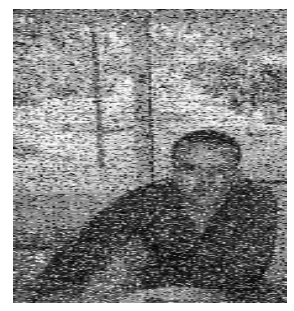

$\mathrm{SNR}=5 \mathrm{~dB}$, $\mathrm{PSNR}=12.76 \mathrm{~dB}$.

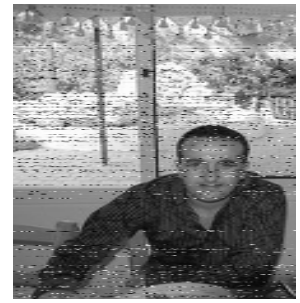

$\mathrm{SNR}=5.75 \mathrm{~dB}$

$\mathrm{PSNR}=19.41 \mathrm{~dB}$.

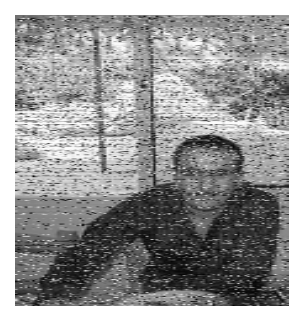

$\mathrm{SNR}=5.5 \mathrm{~dB}$, $\mathrm{PSNR}=14.99 \mathrm{~dB}$.

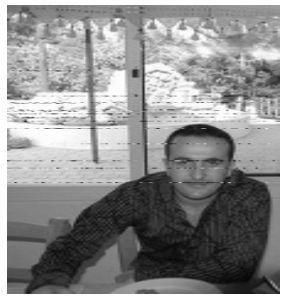

$\mathrm{SNR}=6 \mathrm{~dB}$ PSNR $=26.38 \mathrm{~dB}$.
Figure 4: Decoded Images for $R=1 / 4$ LDPC coded system over Gilbert-Elliot Channel 


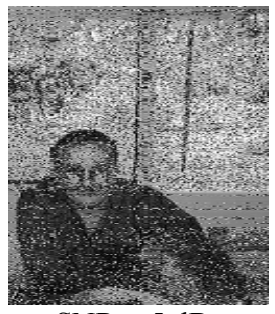

$\mathrm{SNR}=5 \mathrm{~dB}$

$\mathrm{PSNR}=13.45 \mathrm{~dB}$.

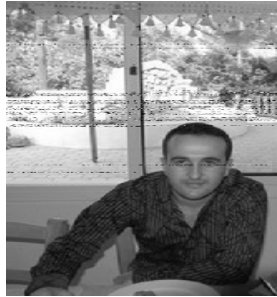

$\mathrm{SNR}=5.75 \mathrm{~dB}$

$\mathrm{PSNR}=24.67 \mathrm{~dB}$.

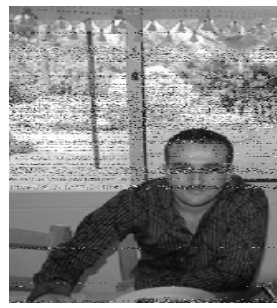

$\mathrm{SNR}=5.5 \mathrm{~dB}$

$\mathrm{PSNR}=18.09 \mathrm{~dB}$.

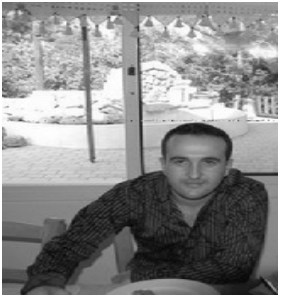

$\mathrm{SNR}=6 \mathrm{~dB}$,

$\mathrm{PSNR}=39.45 \mathrm{~dB}$.
Figure 5: Decoded Images for BCH-LDPC over the GilbertElliot Channel

Comparing the PSNR values for decoded images while using LDPC only and concatenated BCH-LDPC, we see a $13.07 \mathrm{~dB}$ increment in PSNR value at an SNR of $6 \mathrm{~dB}$ when $\mathrm{BCH}$ outer encoder is employed.

Figure 6 shows the BER comparison over the the fading ITU Vehicular channels. On the ITU V-B channel which has a 20 $\mu$ s delay spread the BER performace is an order of magnitude higher at an SNR of $8 \mathrm{~dB}$.

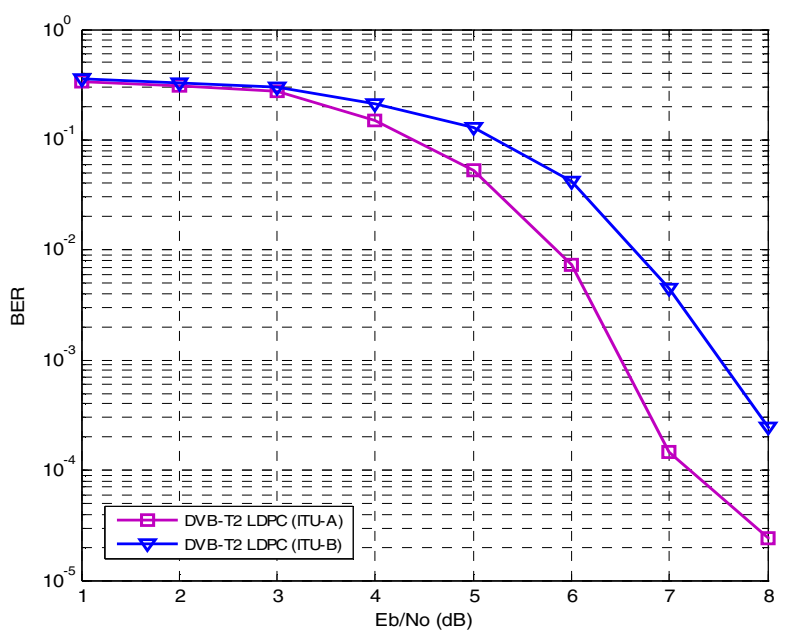

Figure 6: BER performance of $R=1 / 4$ LDPC only coded system over ITU-A and ITU-B Vehicular Channels

Also Figure 7 shows the performance increment in the waterfall region that comes from employing an external $\mathrm{BCH}$ coder together with the rate $1 / 4$ LDPC code. The improvement starts to become apparent after $6 \mathrm{~dB}$. Even though it has not been demonstarted by this paper an other advantage of the outer $\mathrm{BCH}$ code is that it can be used to lower the error floor that is encountered when LDPC only coding is used.

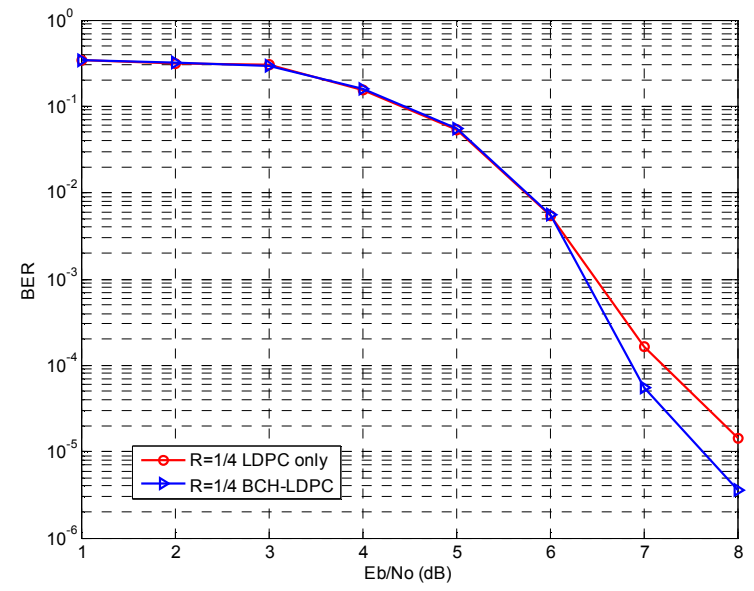

Figure 7: BER performance of $R=1 / 4$ LDPC only and $R=1 / 5$ (effective) BCH-LDPC coded system over ITU-A Vehicular Channel

\section{CONCLUSIONS}

The paper has investigated the use of LDPC-only and concatenated $\mathrm{BCH}-\mathrm{LDPC}$ coding for image transmission over Gilbert-Elliot and ITU Vehicular-A and Vehicular-B fading channels. The results obtained from simulations indicate that the concatenation of an outer $\mathrm{BCH}$ coder with the LDPC inner encoder helps improve the system performance specificly in the waterfall region. The same is also true over the GilbertElliot channel which is known to introduce burst errors.

\section{REFERENCES}

[1] ETSI EN 302755 V1.1.1(2009-09): Digital Video Broadcasting (DVB): Frame structure channel coding and modulation for a second generation digital terrestrial television broadcasting system (DVB-T2), Sept. 2009.

[2] K. Fagervik and A. S. Larssen, "Performance and complexity comparison of low density parity check codes and turbo codes,"in Proc.Norwegian Signal Processing Symposium, (NORSIG '03), Bergen, Norway, pp. 2-4, Oct. 2003.

[3] T. J. Richardson "Error floors of LDPC codes", Proc. Allerton Conf. Communications, Control and Computing, pp.1426-1435, 2003.

[4] G. Liva, E. Paolini, and M. Chiani, "Packet loss recovery in the telemetry downlink via maximum-likelihood LDPC decoding," in Proc. of the 10th Int. Workshop on Signal Processing for Space Communications, Rhodes Island, Greece, pp. 1-6, Oct. 2008.

[5] H. T. Lim , S. H. Lee and E. K. Joo "Performance of concatenated code with hierarchical modulation in T-DMB system", Proc. of Int. Conf. on Electrical and Computer Engineering, pp.282-285, Dec. 2006.

[6] W.C. Jakes, Microwave Mobile Communications, Piscataway, NJ:IEEE Press, 1994.

[7] R. G., Gallager; "Low-density parity-check codes,"Information Theory, IRE Transactions on, vol.8, no.1, pp.21-28, Jan. 1962 .

[8] D. J.C. Mackay; R. Neal; "Near Shannon Limit Performance of Low Density Parity Check Codes", Electronics Letter, Vol.33, pp. 457-458,Mar. 1997.

[9] G. D. Forney Jr. "On decoding BCH codes", IEEE Trans. Inf. Theory, vol. 11, p.549-557, 1965.

[10] Digital Video Broadcasting, "Frame structure channel coding and modulation for a second generation digital terrestrial television broadcasting system (DVB-T2)," DVB Document A122, June 2008. 